\title{
PENGARUH DANA PIHAK KETIGA DAN MODAL SENDIRI TERHADAP TOTAL PEMBIAYAAN PADAKOPERASI PEDAGANG PASAR SYARIAH TANAH ABANG JAKARTA PUSAT
}

\author{
Tri Wartono *)
}

*)dosen universitas pamulang : email : tri.wartono@gmail.com

\section{ARTICLES \\ INFORMATION}

JURNAL SEKURITAS

(Saham, Ekonomi, Keuangan dan Investasi )

Vol.1, No.3, Maret 2018

Halaman : $84-106$

C LPPM \& Prodi Manajemen

UNVERSITAS PAMULANG

ISSN (online) : 2581-2777

ISSN (print) : :2581-2696

\section{Keyword :}

Dana pihak ketiga, modal sendiri, pembiayaan dan Koperasi Syari'ah.

JEL. classification : C32, G20, G23, N65

\section{Contact Author :}

PRODI MANAJEMEN UNPAM

JL.Surya Kencana No.1 Pamulang

Tangerang Selatan - Banten

Telp. (021) 7412566, Fax (021) 7412491 Email :

jurnalfinance.unpam@gmail.com
Tujuan dari penelitian ini aalah untuk mengetahui perkembangan dana pihak ketiga, perkembangan modal sendiri dan pertumbuhan pembiayaan sekaliogus untuk mengethui seberapa besar pengaruh dana pihak ketiga dan modal sendiri baik secara parsial simultan terhadap pembiayaan pada KOPPAS Tanah Abang Jakarta Pusat.

Metode analisis meliputi analisis perkembangan dana pihak ketiga, modal sendiri dan ptotal pembiayaan selama 6 tahun, dengan SPSS 2,0

Hasil penelitian menunjukan bahwa modal sendiri mengalami penurunan rara-rata sebesar 217 juta per tahun, dana pihak ketiga mengalami kenaikan dengan rata-rata pertahun sebesar 1.920 juta, sedangkan pembiayaan mengalami penurunan dengan rata-rata pertahun sebesar 446 juta. Terdapat pengaruh positif dan sangat signifikan antara modal sendiri terhadap pembiayaan yang disalurkan. Sedangkan terdapat pengaruh tidak signifikan antara dana pihak ketiga terhadap pembiayaan yang disalurkan. Secara simultan berpengaruh positif dan signifikan terhadap pembiayaan yang disalurkan.

The purpose of this research is to know the development of third party funds, the development of own capital and the growth of financing at once to know how big the influence of third party funds and own capital either partially simultaneously to financing at KOPPAS Tanah Abang Central Jakarta.

The analysis method includes analysis of third party fund developments, own capital and ptotal financing for 6 years, with SPSS 2.0

The results showed that the capital itself experienced a decrease of 217 million rupiah per year, third party funds increased by an average of 1.920 million per year, while the financing decreased with an average of 446 million per year. There is a positive and very significant influence between the capital itself to the financing discharged. While there is a non-significant influence between third party funds on financing disbursed. Simultaneously have a positive and significant effect on the financing discharged 


\section{A. Pendahuluan}

Pada masa kini atau masa yang akan datang, masyarakat masih membutuhkan layanan usaha koperasi. Alasan utama kebutuhan tersebut adalah dasar pemikiran ekonomi dalam konsep pendirian koperasi, seperti untuk meningkatkan kekuatan penawaran (bargaining position), peningkatan skala usaha bersama, pengadaan pelayanan yang selama ini tidak ada, serta pengembangan kegiatan lanjutan (pengolahan, pemasaran dan sebagainya) dari kegiatan anggota. Alasan lain adalah karena adanya peluang untuk mengembangkan potensi usaha tertentu (yang tidak berkaitan dengan usaha anggota) atau karena memanfaatkan fasilitas yang disediakan pihak lain (pemerintah) yang mensyaratkan kelembagaan koperasi, sebagaimana bentuk praktek pengembangan koperasi yang telah dilakukan selama ini.

Koperasi adalah badan usaha yang beranggotakan orang seorang atau badan hukum koperasi dengan melandaskan kegiatannya berdasarkan prinsip koperasi sekaligus sebagai gerakan ekonomi rakyat yang berdasar atas asas kekeluargaan (Sholahuddin dan Hakim, 2008: 179). Koperasi Jasa Keuangan Syariah selanjutnya disebut KJKS adalah koperasi yang kegiatan usahanya bergerak dibidang pembiayaan, investasi dan simpan pinjam sesuai pola bagi hasil (syariah).

Perusahaan yang bergerak dibidang keuangan memegang peranan sangat penting dalam memenuhi kebutuhan dana. Hal ini disebabkan perusahaan keuangan memang bidang utama usahanya adalah menyediakan fasilitas pembiayaan dana untuk perusahaan lainnya, sebab hampir tidak ada bidang usaha yang tidak memerlukan dana. Dana merupakan masalah pokok yang selalu ada dan selalu muncul dalam setiap usaha (Kasmir, 2005:1-2).

Koperasi merupakan bagian dari tata susunan ekonomi, hal ini berarti bahwa dalam kegiatannya koperasi turut mengambil bagian bagi tercapainya kehidupan ekonomi, baik bagi orang-orang yang menjadi anggota perkumpulan itu sendiri maupun untuk masyarakat di sekitarnya. Koperasi sebagai perkumpulan untuk kesejahteraan bersama, melakukan usaha dan kegiatan di bidang pemenuhan kebutuhan bersama dari para anggotanya.

Alasan kebutuhan awal atas keberadaan koperasi tersebut sangat dipengaruhi oleh pola hubungan koperasi dan anggota serta masyarakat yang didominasi pola hubungan bisnis. Kegiatan usaha yang dikembangkan koperasi pada prinsipnya adalah kegiatan yang berkait dengan kepentingan anggota. Biaya transaksi yang ditimbulkan apabila anggota menggunakan koperasi dalam melakukan kegiatan usahanya lebih kecil jika dibandingkan dengan tanpa koperasi. Hal ini akan menjadi penentu apakah keberadaan koperasi dan keanggotaan koperasi memang memberikan manfaat bisnis. Jika biaya transaksi tersebut memang dapat menjadi insentif bagi keanggotaan koperasi maka produktivitas modal koperasi akan lebih besar dibandingkan lembaga lain. Langkah selanjutnya yang perlu dikembangkan oleh suatu koperasi adalah agar hasil produktifitas tersebut dapat dipertahankan dalam sistem koperasi.

Koperasi Pedagang Pasar (KOPPAS) Tanah Abang Syariah sebagai lembaga ekonomi yang berwatak sosial, juga berusaha melalui berbagai bidang ekonomi untuk mensejahterakan Anggota dan masyarakat pada umumnya. Salah satu usaha yang digarap dan telah berjalan sekitar 36 tahun adalah Unit Jasa Keuangan, memberikan kontribusi yang cukup besar bagi kesejahteraan anggota dan keberlangsungan hidup organisasi KOPPAS Tanah Abang Syariah. Sejak diberlakukannya sistem syariah secara penuh mulai tahun buku 2005, perkembangan modal KOPPAS Tanah Abang Syariah menunjukkan perkembangan yang cukup signifikan, namun penambahan modal tersebut lebih banyak diakibatkan oleh penambahan modal dari pihak ketiga.

Sebagai akibat kurangnya modal sendiri, sementara permintaan pembiayaan dari Anggota semakin meningkat, maka Pengurus KOPPAS Tanah Abang Syariah berupaya mendapatkan/meminjam dana dari Pihak Ketiga (Perbankan Syariah, Lembaga Pengelola Dana Bergulir (LPDB), Kementerian Koperasi dan UKM Republik Indonesia, Tabungan, 
Simpanan Berjangka dan lain-lain). Semakin besarnya dana pihak ketiga yang digunakan dalam transaksi simpan-pinjam pada UJKS KOPPAS Tanah Abang Syariah ditunjukkan dalam tabel 1.1 di bawah, dimana terjadi peningkatan yang signifikan tahun 2011 sampai dengan tahun 2013, menurun di tahun 2014-2015 kemudian meningkat kembali tahun 2016.

Tabel 1.1

Modal, Dana Pihak Ketiga dan Pembiayaan KOPPAS Tanah Abang Syariah (Dalam Jutaan Rupiah)

\begin{tabular}{|l|c|c|c|c|c|c|}
\hline \multicolumn{1}{|c|}{$\begin{array}{c}\text { Keterangan } \\
\text { /Tahun }\end{array}$} & 2011 & 2012 & 2013 & 2014 & 2015 & 2016 \\
\hline Modal Sendiri & 4.899 & 5.304 & 5.927 & 6.985 & 6.677 & 3.597 \\
\hline Simp. Berjangka & 3.881 & 5.401 & 6.886 & 8.006 & 5.709 & 6.696 \\
\hline Tabungan & 2.268 & 3.102 & 4.009 & 4.230 & 4.131 & 4.740 \\
\hline $\begin{array}{l}\text { Hutang ke Lembaga } \\
\text { lainnya }\end{array}$ & 4.459 & 6.714 & 8.439 & 2.007 & 2.253 & 11.976 \\
\hline Total Dana Pihak ke III & 10.608 & 15.217 & 19.334 & 14.243 & 12.093 & 22.269 \\
\hline Pembiayaan & 13.007 & 15.380 & 17.994 & 17.627 & 12.933 & 10.341 \\
\hline
\end{tabular}

Sumber: Laporan Musyawarah Anggota Tahunan KOPPAS Tanah Abang Syariah Tahun 2011-2016

Sementara itu perkembangan modal sendiri (simpanan pokok, simpanan wajib, simpanan wajib khusus, simpanan sukarela dan cadangan Koperasi) sangat lambat, sehingga modal dari pihak ketiga sangat diperlukan. Berdasarkan uraian pada latar belakang masalah di atas, peneliti tertarik untuk meneliti lebih lanjut tentang modal sendiri, dana pihak ketiga dan pembiayaan di KOPPAS Tanah Abang Syariah. Adapun judul penelitian yang akan dilakukan adalah sebagai berikut: "Pengaruh Peranan Modal Sendiri dan Dana Pihak Ketiga Terhadap Pembiayaan Pada KOPPAS Tanah Abang Syariah"

\section{Identifikasi Masalah}

Berdasarkan latar belakang masalah di atas, maka dapat diidentifikasikan permasalahan yang ada selama ini terjadi pada UJKS KOPPAS Tanah Abang Syariah sebagai berikut :

a. Penambahan sumber dana lebih banyak diakibatkan dari pihak ketiga.

b. Permintaan pembiayaan dari anggota meningkat.

c. Perkembangan modal sendiri (simpanan pokok, simpanan wajib, simpanan wajib khusus, simpanan sukarela dan cadangan Koperasi) yang sangat lambat.

d. Penyaluran pembiayaan berfluktuatif pada tahun ke tahun.

\section{Pembatasan Masalah}

Berdasarkan identifikasi masalah diatas maka penulis membatasi masalah sebagai berikut:

a. Modal sendiri adalah modal yang di peroleh dari anggota pendiri usaha itu sendiri yang terdiri dari simpanan pokok, simpanan wajib, simpanan wajib khusus, simpanan sukarela dan cadangan.

b. Dana pihak ketiga adalah dana yang berasal dari pihak ketiga (simpanan atau hutang dari Non-anggota) yaitu berupa simpanan berjangka, tabungan, dan pinjaman lembaga lainnya yang sewaktu-waktu dapat ditarik kembali baik secara sekaligus maupun berangsur. 
c. Pembiayaan adalah pemberian fasilitas dana untuk memenuhi kebutuhan anggota dan nasabah untuk membiayai modal usahanya.

d. Objek penelitian dilakukan pada KOPPAS Tanah Abang Syariah dan data yang diteliti adalah laporan keuangan periode 2011-2016.

e. Waktu penelitian dilakukan pada bulan Februari 2017.

\section{Perumusan Masalah}

Berdasarkan latar belakang masalah di atas, maka yang menjadi pokok masalah dalam penelitian ini adalah:

a. Bagaimana perkembangan modal sendiri, dana pihak ketiga dan pembiayaan pada KOPPAS Tanah Abang Syariah?

b. Bagaimana pengaruh modal sendiri secara parsial terhadap pembiayaan pada KOPPAS Tanah Abang Syariah?

c. Bagaimana pengaruh dana pihak ketiga secara parsial terhadap pembiayaan pada KOPPAS Tanah Abang Syariah?

d. Bagaimana pengaruh modal sendiri dan dana pihak ketiga secara bersamasama terhadap pembiayaan pada KOPPAS Tanah Abang Syariah?

\section{Tujuan dan Manfaat Penelitian}

\section{a. Tujuan Penelitian}

Adapun Tujuan yang ingin dicapai dari penelitian adalah:

1) Untuk mengetahui tingkat perkembangan modal sendiri, dana pihak ketiga dan pembiayaan di KOPPAS Tanah Abang Syariah

2) Untuk mengetahui pengaruh modal sendiri terhadap penyaluran pembiayaan di KOPPAS Tanah Abang Syariah.

3) Untuk mengetahui pengaruh dana pihak ketiga terhadap pembiayaan di KOPPAS Tanah Abang Syariah.

4) Untuk mengetahui pengaruh peranan modal sendiri dan dana pihak ketiga secara bersama-sama dalam penyaluran pembiayaan di KOPPAS Tanah Abang Syariah.

\section{b. Manfaat Penelitian}

Adapun kegunaan dari hasil penelitian ini adalah sebagai berikut:

1) Bagi KOPPAS Tanah Abang Syariah.

Dengan adanya penelitian ini diharapkan dapat memberikan masukan yang bermanfaat berupa sumbangan ide-ide membangun bagi KOPPAS Tanah Abang Syariah dalam mengetahui tingkat modal sendiri dan dana pihak ketiga khususnya untuk melakukan aktifitas mengolah dana, sehingga dapat mengambil langkahlangkah untuk perbaikan.

2) Bagi Penulis

Untuk menambah wawasan pengetahuan sebagai bekal agar dapat menerapkan kombinasi yang tepat antara keadaan teoritis dengan keadaan yang sebenarnya, khususnya mengenai modal sendiri dan dana pihak ketiga dalam pembiayaan.

3) Bagi Pihak Lain

Penelitian ini diharapkan dapat berguna untuk mendapatkan pengetahuan dan sebagai bahan pertimbangan lainnya yang mungkin digunakan untuk penelitian lebih lanjut.

\section{Kerangka Berfikir}

Modal yang dimiliki sendiri oleh KOPPAS Tanah Abang Syariah sangat berpengaruh terhadap kelangsungan koperasi. Yang mana dana yang diperoleh akan diolah kembali dalam bentuk penyaluran pembiayaan kepada anggota selama jangka waktu tertentu. Tingkat permintaan pembiayaan akan mempengaruhi ketersediaan modal yang dimiliki sendiri. Sehingga apabila modal yang dimiliki tidak mencukupi untuk permintaan 
pembiayaan anggota, maka hal yang dilakukan adalah meningkatkan sumber dana dari pihak ketiga. Berdasarkan uraian diatas, dapat dibuat kerangka berfikir sebagai berikut :

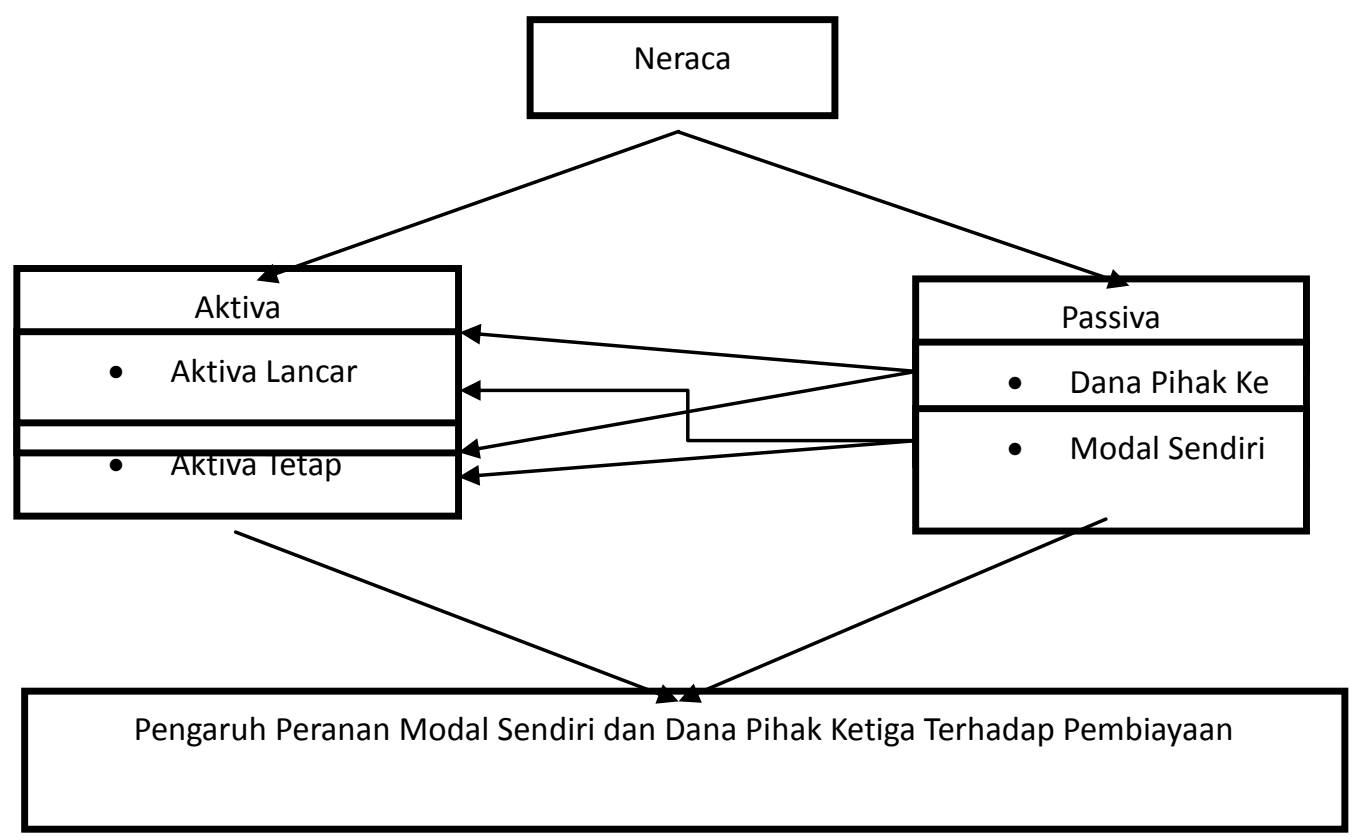

Gambar 1.1 Kerangka Berfikir

\section{Hipotesis Penelitian}

Hipotesis merupakan jawaban sementara terhadap masalah yang masih bersifat praduga karena masih harus dibuktikan kebenarannya yang disusun oleh peneliti yang kemudian akan diuji kebenarannya melalui penelitian yang dilakukan. Menurut Sugiyono (2002:51) "Hipotesis adalah jawaban sementara terhadap rumusan masalah penelitian, oleh sebab itu rumusan malasah penelitian biasanya di susun dalam bentuk kalimat pertanyaan" Untuk memudahkan penjabaran rumusan hipotesis, maka penulis menggambarkan desain penulisan sebagai berikut :

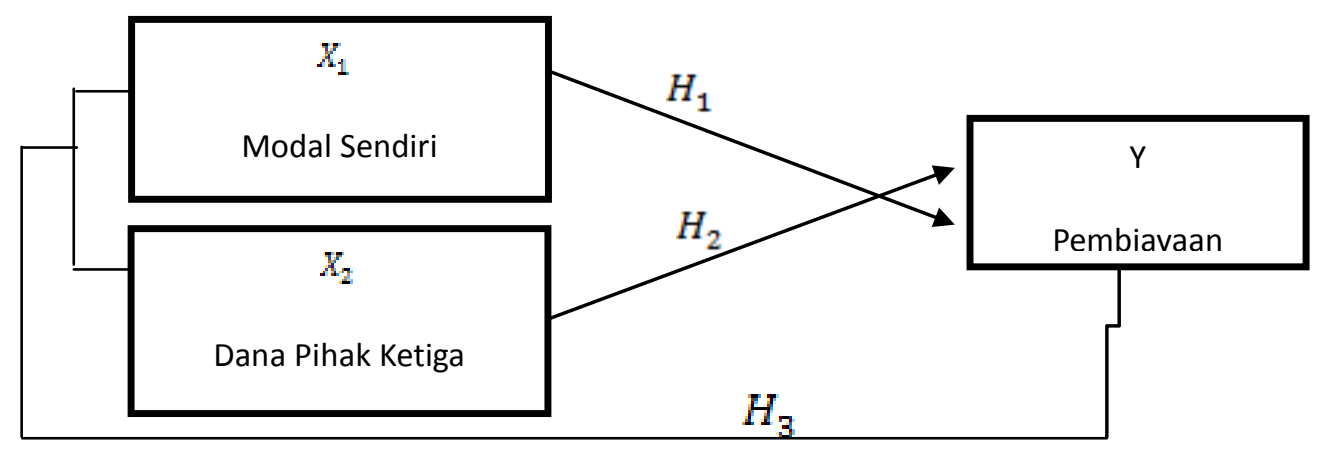

\section{Gambar 1.2 Desain Penelitian}

Adapun rumusan hipotesis dalam penelitian ini dinyatakan sebagai berikut:

$\mathrm{H}_{1} \quad$ : Modal sendiri berpengaruh positif terhadap pembiayaan

$\mathrm{H}_{2}$ : Dana pihak ketiga berpengaruh positif terhadap pembiayaan

$\mathrm{H}_{3} \quad$ : Modal sendiri dan dana pihak ketiga secara bersama-sama

Syariah berpengaruh terhadap pembiayaan pada KOPPAS Tanah Abang 


\section{B. Tinjauan Pustaka \\ 1. Koperasi Jasa Keuangan Syariah (KJKS) di Indonesia \\ a. Pengertian Koperasi Jasa Keuangan Syariah (KJKS)}

Koperasi jasa keuangan syariah adalah lembaga keuangan mikro yang dalam pengoperasiannya menggunakan prinsip prinsip ekonomi syariah. Yaitu dengan kesepakatan bagi hasil. Tujuan koperasi jasa keuangan syariah sama dengan koperasi pada umumnya yaitu meningkatkan perekonomian dan mengembangkan bisnis usaha mikro dan menengah dalam rangka mengangkat harkat dan martabat kaum kecil dan menengah. Koperasi ini tumbuh berdasarkan kesepakatan dari sekelompok orang yang bersedia menyetorkan dananya untuk dioperasikan. Selain itu fondasi modal dari koperasi jasa keuangan syariah berasal dari simpanan-simpanan para anggota dan masyarakat yang bergabung. Adapun jenis simpanan tersebut adalah simpanan sukarela, simpanan wajib dan simpanan pokok. Bagi anggota pendiri ada simpanan pokok khusus.

Dana yang terkumpul dari simpanan tersebut lalu diolah dengan cara disalurkan melalui produk pembiayaan dan jasa. Berbeda dengan koperasi biasa yang menggunakan bunga konsep pembiayaan pada koperasi jasa keuangan mengunakan sistem kesepakatan dan bagi hasil dengan menggunakan akad muhdorobah, musyarokah, dan syirkah. Sistem bagi hasil merupakan pengaplikasian dari konsep ekonomi syariah yang berupaya keras menghindari riba. Pada Sistem Bagi Hasil, yang dibagi adalah keuntungan yang diperoleh oleh peminjam yang menjalankan usaha. Setiap keuntungan yang ada di bagi berdasarkan kesepakan dengan pihak KJKS. Pada Sistem Bagi Hasil pun terdapat pembagian resiko, dimana apabila usaha dari peminjam mengalami kerugian maka pihak KJKS juga ikut bersama-sama menanggung kerugian tersebut dengan syarat kerugian tersebut bukan disebabkan karena kelalaian, kesalahan, atau kesengajaan dari pihak peminjam.

Selain itu KJKS juga menyediakan pembiayaan dengan akad jual beli atau sering disebut murobahah. Murobahah perjanjian jual-beli antara anggota dengan pihak KJKS. KJKS membeli barang yang diperlukan anggota kemudian menjualnya kepada anggota yang bersangkutan sebesar harga perolehan ditambah dengan margin keuntungan yang disepakati antara KJKS dan anggota. Kemudian anggota yang bersangkutan membayar harga barang beserta margin yang telah disepakati dengan cara mengangsur. Konsep seperti ini juga sangat baik dan sangat membantu meringankan masyarakat untuk memenuhi kebutuhannya. Selain itu KJKS memiliki lembaga khusus, yaitu lembaga pengumpul dana dari masyarakat untuk zakat, infaq dan sodaqoh, dana tersebut akan disalurkan kembali ke masyarakat sebagai dana sosial, dana ini biasanya diberikan secara sukarela kepada masyarakat yang benar benar membutuhkan selain itu biasanya pihak KJKS membuat program perencanaan dan pelatihan kewirausaan kepada masyarakat yang menerima dana sosial dan sukarela dari lembaga zakat, infaq dan shodaqoh. KJKS yang memiliki lembaga seperti ini biasanya bernama Baitul Mal Wat Tamwil (BMT)

Dengan begitu KJKS sebagai lembaga keuangan mikro syariah berperan sebagai pilar ekonomi ditengah masyarakat, karena keberadaan KJKS ditengah masyarakat mampu memberdayakan perekonomian kerakyatan dengan usaha kecil dan menengah. Dan perkembangan usaha kecil merupakan gambaran dari suatu masyarakat yang produktif, dimana masyarakat dapat menunjukan keahlian serta kemandiriannya. Tidak hanya itu, usaha-usaha kecil ini juga dapat membantu pemerintah dalam penyerapan tenaga kerja yang selama ini menjadi masalah dalam pemerintahan karena usaha dengan mengurangi angka pengangguran dengan meningkatkan kesempatan kerja. Krisis perekonomian yang sering menjadi alibi dalam memburuknya keadaan perekonomian nasional. Namun, tersebarnya usaha kecil di berbagai daerah dengan berbagai jenis usaha dalam bentuk barang dan jasa dapat menjadi sebuah peluang yang wajib diperhitungkan untuk memulihkan perekonomian saat ini yang sedang di ambang 
kehancuran. Hal ini dikarenakan usaha kecil bergerak di lapisan bawah ekonomi yang bergerak langsung di masyarakat.

Oleh karena itu sangat disarankan untuk mengembangkan KJKS di setiap daerah yang ada untuk membantu menuntaskan masalah perekonomian kelas kecil dan menengah di daerah dengan landasan syariah yang sangat dianjurkan oleh agama Islam karena menghindari dan menolak keras riba. Sekalipun KJKS menggunakan konsep syariah yang cenderung identik dengan umat islam, bukan berarti hanya masyarakat muslim saja yang bisa bergabung menjadi anggota dan menggunakan jasa KJKS. KJKS dan konsep syariah yang digunakan bisa dinikmati oleh umat manapun tak memandang agama dan suku karena pada dasarnya konsep syariah adalah konsep ekonomi yang universal yang berkeadilan.

\section{b. Permodalan Koperasi}

Setiap perkumpulan atau organisasi dalam melakukan kegiatan untuk mencapai tujuannya memerlukan sejumlah dana. Sebagai badan usaha, koperasi memerlukan dana sesuai dengan lingkup dan jenis usahanya. Dalam rangka mendirikan badan usaha koperasi, yang ditetapkan oleh pembuat undang-undang sebagai syarat minimum untuk mendirikan sebuah koperasi adalah jumlah anggota pendiri. Sedangkan besar modal minimum yang harus disetor sebagai modal awal koperasi oleh para pendirinya tidak ditentukan. hal ini sesuai dengan karakteristik koperasi yang mengedepankan jumlah anggota daripada besar modal usaha.

\section{c. Karakteristik Koperasi}

Koperasi merupakan sebuah perkumpulan dari orang-orang yang mempunyai tujuan bersama untuk bekerja sama dalam memperbaiki dan meningkatkan taraf kemampuan mereka di bidang ekonomi dan perekonomian. Unsur-unsur penting dari kalimat tersebut adalah adanya orang-orang, yang berumpul dalam sebuah perkumpulan, mempunyai tujuan yang sama dengan bekerja sama, di dalam bidang kesejahteraan ekonomi. Jadi sejak awal sebuah koperasi menjalankan usahanya, para pengurus dan anggota koperasi secara sadar dan wajib memanfaatkan jasa atau produk yang dihasilkan oleh koperasi mereka sendiri, sebagai cara utama untuk ikut memajukan koperasi dalam memupuk modal.

\section{d. Peruntukan Modal}

Sedikitnya ada tiga alasan koperasi membutuhkan modal, anatara lain: Pertama, untuk membiayai proses pendirian sebuah koperasi atau disebut biaya pra-organisasi untuk keperluan: pembuatan akta pendirian atau anggaran dasar, membayar biaya administrasi pengurusan izin yang diperlukan, sewa tempat bekerja, ongkos transportasi, dan lain-lain Kedua, untuk membeli barang-barang modal. Barang-barang modal ini dalam perhitungan perusahaan digolongkan menjadi harta tetap atau barang modal jangka panjang. Ketiga, untuk modal kerja. Modal kerja biasanya digunakan untuk membiayai operasional koperasi dalam menjalankan usahanya.

Pengertian modal dalam sebuah organisasi perusahaan termasuk badan koperasi adalah sama, yaitu modal yang digunakan untuk menjalankan usaha. Koperasi merupakan kumpulan dari orang-orang yang mengumpulkan modal untu modal usaha dan setiap orang mempunyai hak yang sama.

\section{e. Sumber Modal Koperasi}

Tujuan utama mendirikan sebuah organisasi koperasi adalah untuk mengakumulasikan potensi keuangan para pendiri dan anggotanya yang meskipun pada awalnya berjumlah kecil tetapi tetap ada. Modal terdiri dari 2 jenis, yaitu modal jangka panjang yang berupa 
fasilitas fisik dan modal jangka pendek yaitu untuk kegiatan operasional usaha koperasi dilakukan bersama dan dibangun dengan modal bersama.

Menurut Undang-Undang Perkoperasian, modal koperasi terdiri dari modal sendiri dan modal pinjaman.

\section{1) Modal Sendiri}

Modal sendiri adalah modal berupa aset maupun dana yang dimiliki oleh pemilik perusahaan atau pendiri perusahaan. Modal sendiri yang dimiliki koperasi sendiri adalah modal yang berupa :

a) Simpanan Wajib adalah sejumlah uang yang wajib dibayarkan anggota dalam jangka waktu tertentu. Biasanya dibayar tiap bulan. Jumlah simpanan wajib tidak harus sama untuk tiap anggota. Simpanan wajib tidak dapat diambil kembali selama yang bersangkutan masih menjadi anggota.

b) Simpanan Khusus adalah simpanan yang besarnya tidak di tentukan, tetapi bergantung kepada kemampuan anggota. Simpanan sukarela dapat di setorkan setiap saat tetapi hanya bisa diambil sesuai jangka waktu tertentu ( 1 tahun)

c) Simpanan Sukarela merupakan simpanan yang jumlah dan waktu pembayarannya tidak ditentukan. Simpanan sukarela dapat diambil anggota sewaktu-waktu.anggota koperasi.

d) Dana cadangan adalah sejumlah uang yang diperoleh dari penyisihan Sisa Hasil Usaha (SHU). Dana cadangan berfungsi untuk memupuk modal sendiri dan untuk menutup kerugian koperasi bila diperlukan.

e) Dana hibah adalah dana pemberian dari orang atau lembaga lain kepada koperasi.

\section{2) Pinjaman Dana Pihak Ketiga}

Sumber dana dari pihak ketiga merupakan sumber dana terpenting bagi kegiatan operasional lembaga keuangan dan merupakan ukuran keberhasilan koperasi jika mampu membiayai operasinya dari sumber dana ini. Pencarian dana ini relatif paling mudah jika dibandingkan dengan sumber dana lainnya. Mudah dikarenakan asal dapat memberikan bagi hasil yang relatif lebih tinggi dan dapat memberikan fasilitas menarik lainnya seperti hadiah dan pelayanan yang memuaskan.

Dana pihak ketiga ini berasal dari : (1) Simpanan Koperasi Berjangka adalah simpanan dana dalam jumlah tertentu dan dalam jangka waktu tertentu. Simpanan ini tidak bisa diambil sewaktu-waktu. (2) Tabungan merupakan dana yang dihimpun dari nasabah atau anggota koperasi yang jumlah dan waktunya tidak ditentukan. Dana ini bisa diambil sewaktu-waktu. (3) Dana dari Lembaga lainnya yaitu sumber dana yang diperoleh dari lembaga keuangan lainnya.

\section{f. Distribusi Modal Koperasi}

\section{Distribusi Cadangan Koperasi}

Cadangan menurut UU No. 25/1992, adalah sejumlah uang yangdiperoleh dari penyisihan sisa hasil usaha yang dimasukkan untuk memupuk modal sendiri dan untuk menutup kerugian koperasi bila diperlukan. Sesuai Anggaran Dasar yang menunjuk pada UU No. 12/1967 menentukan bahwa $25 \%$ dari Sisa Hasil Usaha (SHU) yang diperoleh dari usaha anggota disisihkan untuk cadangan, sedangkan SHU yang berasal bukan dari usaha anggota sebesar $60 \%$ disisihkan untuk cadangan. Banyak sekali manfaat distribusi cadangan, seperti: (1) Memenuhi kewajiban tertentu (2) Meningkatkan jumlah operating capital koperasi (3) Sebagai jaminan untuk kemungkinan kemungkinan rugi di kemudian hari (4) Perluasan usaha.

\section{Penyaluran Pembiayaan}

Pembiayaan adalah pemberian fasilitas dana untuk memenuhi kebutuhan anggota dan nasabah untuk membiayai modal usahanya. Pembiayaan dalam koperasi syariah adalah sebagai berikut : 


\section{a. Pembiayaan Mudharabah}

Pembiayaan mudharabah adalah akad kerjasama antara koperasi syariah selaku pemilik dana (shahibul maal) dengan nasabah selaku (mudharib) yang mempunyai keahlian atau ketrampilan untuk mengelola suatu usaha yang produktif dan halal. Hasil keuntungan dari penggunaan dana tersebut dibagi bersama berdasarkan nisbah yang disepakati.

\section{b. Pembiayaan Murabahah}

Pembiayaan Murabahah adalah perjanjian jual beli antara bank dan nasabah, dimana bank islam membeli barang yang diperlukan oleh nasabah dan kemudian menjualnya kepada nasabah yang bersangkutan sebesar harga perolehan ditambah dengan margin atau keuntungan yang disepakati antara koperasi syariah dan nasabah.

\section{c. Pembiayaan ljarah}

Pembiayaan ljarah adalah perjanjian sewa menyewa suatu barang dalam waktu tertentu melalui pembayaran sewa.

\section{d. Pembiayaan Hawalah}

Pembiayaan Hawalah adalah akad Perpindahan Hutang dari tanggungan Ashil (Muhil) I Pihak ke tiga kepada Muhal 'Alaih/anggota, calon anggota, koperasi lain, dan atau anggotanya (orang yang bertanggung jawab setelah Hiwalah) dengan dikenakan biaya penanggungan (upah/Ujroh) atas hutang atau kewajiban tersebut.

\section{Penelitian Terdahulu}

Beberapa penelitian terdahulu akan diuraikan secara ringkas oleh penulis karena penelitian ini mengacu pada beberapa penelitian sebelumnya. Meskipun ruang lingkup hampir sama tetapi karena objek, periode, waktu dan alat analisis yang digunakan berbeda, maka terdapat banyak hal yang tidak sama sehingga dapat dijadikan sebagai referensi untuk saling melengkap.

Adapun penelitian-penelitian tersebut dijelaskan pada tabel di bawah ini :

a. Beberapa Hasil Penelitian terdahulu

Tabel 2.1

Penelitian Terdahulu

\begin{tabular}{|c|c|c|c|c|}
\hline No. & Penelitian & Alat Analisis & Variabel & Hasil Penelitian \\
\hline 1 & $\begin{array}{l}\text { Kholisatun Ni'mah } \\
\text { (2015), Analisis } \\
\text { Pengaruh Dana } \\
\text { Pihak Ketiga } \\
\text { (DPK), Modal } \\
\text { Sendiri, Return On } \\
\text { Asset (ROA), dan } \\
\text { Financing to } \\
\text { Deposit Ratio } \\
\text { (FDR) Terhadap } \\
\text { Pembiayaan yang } \\
\text { Disalurkan Pada } \\
\text { Bank BRI Syariah } \\
\text { Pada Tahun 2010- } \\
2014\end{array}$ & $\begin{array}{l}\text { Uji } \\
\text { Deskriptif, } \\
\text { Asumsi } \\
\text { Klasik, } \\
\text { Analisis } \\
\text { Regresi } \\
\text { Linier } \\
\text { Berganda, } \\
\text { Uji F dan Uji } \\
\text { T }\end{array}$ & $\begin{array}{l}\text { Variabel } \\
\text { Independen : } \\
\text { Dana Pihak } \\
\text { Ketiga, } \\
\text { Modal } \\
\text { Sendiri, } \\
\text { Return On } \\
\text { Asset, } \\
\text { Financing to } \\
\text { Deposit Ratio } \\
\text { Variabel } \\
\text { Dependen : } \\
\text { Pembiayaan }\end{array}$ & $\begin{array}{l}\text { Dana Pihak Ketiga dan } \\
\text { Financing to Deposit Ratio } \\
\text { dinyatakan signifikan } \\
\text { berpengaruh terhadap } \\
\text { pembiayaan, ada pengaruh } \\
\text { secara simultan antara Dana } \\
\text { Pihak Ketiga, Modal Sendiri, } \\
\text { ROA dan FDR terhadap } \\
\text { pembiayaan. }\end{array}$ \\
\hline 2 & $\begin{array}{l}\text { Khadijah, } \\
\text { Hidayyatul Maula } \\
\text { (2008), Pengaruh } \\
\text { Simpanan (Dana } \\
\text { Pihak Ketiga), } \\
\text { Modal Sendiri, }\end{array}$ & $\begin{array}{l}\text { Uji Linier } \\
\text { Berganda }\end{array}$ & $\begin{array}{l}\text { Variabel } \\
\text { Independen : } \\
\text { Dana Pihak } \\
\text { Ketiga, } \\
\text { Modal } \\
\text { Sendiri, }\end{array}$ & $\begin{array}{l}\text { Modal Sendiri dan Marjin } \\
\text { Keuntungan berpengaruh } \\
\text { positif dan signifikan } \\
\text { terhadap pembiayaan } \\
\text { murabahah, NPF } \\
\text { berpengaruh negatif dan }\end{array}$ \\
\hline
\end{tabular}




\begin{tabular}{|c|c|c|c|c|}
\hline & $\begin{array}{l}\text { Marjin Keuntungan } \\
\text { dan Non } \\
\text { Performing } \\
\text { Financial Terhadap } \\
\text { Pembiayaan } \\
\text { Murabahah pada } \\
\text { Bank Syariah }\end{array}$ & & $\begin{array}{l}\text { Marjin } \\
\text { Keuntungan, } \\
\text { Non } \\
\text { Performing } \\
\text { Financing. } \\
\text { Variabel } \\
\text { Dependen : } \\
\text { Pembiayaan } \\
\text { Murabahah }\end{array}$ & $\begin{array}{l}\text { signifikan terhadap } \\
\text { pembiayaan murabahah, } \\
\text { Dana Pihak Ketiga, Modal } \\
\text { sendiri, Marjin Keuntungan } \\
\text { dan Non Performing } \\
\text { Financial secara bersama- } \\
\text { sama berpengaruh positif } \\
\text { dan signifikan terhadap } \\
\text { pembiayaan murabahah. }\end{array}$ \\
\hline 3 & $\begin{array}{l}\text { Wuri Arianti Novi } \\
\text { Pratami } \\
\text { (2011) } \\
\text { Analisis Pengaruh } \\
\text { DPK, CAR, } \\
\text { NPFdan ROA } \\
\text { terhadap } \\
\text { pembiayaan pada } \\
\text { perbankan syariah } \\
\text { (studi kasus pada } \\
\text { Bank Muamalat } \\
\text { Indonesia Periode } \\
\text { 2001-2011) }\end{array}$ & $\begin{array}{l}\text { Regresi } \\
\text { Berganda, } \\
\text { Statistik } \\
\text { Deskripti } \\
\text { f dan Uji } \\
\text { Asumsi } \\
\text { Klasik }\end{array}$ & $\begin{array}{l}\text { Variabel } \\
\text { Independe } \\
\mathrm{n}: \mathrm{DPK}, \\
\text { CAR, } \\
\text { NPF, } \\
\text { ROA. } \\
\text { Variabel } \\
\text { Dependen } \\
: \\
\text { Pembiayaan. }\end{array}$ & $\begin{array}{l}\text { Variabel DPK } \\
\text { Berpengaruh positif signifikan } \\
\text { terhadap } \\
\text { pembiayaan,CAR } \\
\text { tidak pengaruh terhadap } \\
\text { pembiayaan, NPF dan ROA } \\
\text { tidak berpengaruh terhadap } \\
\text { pembiayaan dan secara } \\
\text { simultan semua variabel } \\
\text { DPK, CAR, NPF, } \\
\text { dan ROA berpengaruh } \\
\text { signifikan terhadap } \\
\text { pembiayaan. }\end{array}$ \\
\hline 4 & $\begin{array}{l}\text { Muh Lutfi Qolby } \\
\text { (2013) } \\
\text { Faktor-faktor yang } \\
\text { mempengaruhi } \\
\text { Pembiayaan pada } \\
\text { Perbankan Syariah } \\
\text { Di Indonesia } \\
\text { Periode Tahun } \\
\text { 2007-2013 }\end{array}$ & $\begin{array}{l}\text { OLS } \\
\text { (ordinary } \\
\text { least } \\
\text { square), } \\
\text { dan Uji } \\
\text { Asumsi } \\
\text { Klasik }\end{array}$ & $\begin{array}{l}\text { Variabel } \\
\text { Independe } \\
\mathrm{n}: \mathrm{DPK}, \\
\text { CAR, } \\
\text { LDR, } \\
\text { ROA. } \\
\text { Variabel } \\
\text { Dependen } \\
\vdots \\
\text { Volume } \\
\text { Kredit } \\
\text { yang } \\
\text { disalurkan. }\end{array}$ & $\begin{array}{l}\text { DPK, SWBI dan ROA dalam } \\
\text { jangka pendek maupun } \\
\text { jangka panjang secara } \\
\text { bersama - sama } \\
\text { berpengaruh terhadap } \\
\text { pembiayaan, DPKdan dalam } \\
\text { jangka pendek dan jangka } \\
\text { panjang berpengaruh positif } \\
\text { dan } \\
\text { signifikan terhadap } \\
\text { pembiayaan, SWBI dalam } \\
\text { jangka pendek dan jangka } \\
\text { panjang berpengaruh } \\
\text { negatif dan signifikan } \\
\text { terhadap pembiayaan, ROA } \\
\text { dalam jangka pendek } \\
\text { berpengaruh positif dan tidak } \\
\text { signifikan, sedangkan dalam } \\
\text { jangka panjang Return On } \\
\text { Assets (ROA) berpengaruh } \\
\text { positif dan signifikan } \\
\text { terhadap pembiayaan } \\
\text { perbankan syariah } \\
\text { di Indonesia. }\end{array}$ \\
\hline 5 & $\begin{array}{l}\text { Fitria Ayu, Saryadi } \\
\text { dan Andi Wijayanto } \\
\text { (2011) Pengaruh } \\
\text { DPK, CAR, NPL, } \\
\text { ROA dan LDR } \\
\text { terhadap Volume } \\
\text { Kredit yang }\end{array}$ & $\begin{array}{l}\text { Uji Regresi } \\
\text { Berganda } \\
\text { dan Uji } \\
\text { Asumsi } \\
\text { Klasik }\end{array}$ & $\begin{array}{l}\text { Variabel } \\
\text { Independe } \\
n: \text { DPK, } \\
\text { CAR, } \\
\text { LDR, } \\
\text { ROA. } \\
\text { Variabel }\end{array}$ & $\begin{array}{l}\text { Berpengaruh signifi } \\
\text { kan terhadap Volume Kredit } \\
\text { yang disalurkan, CAR } \\
\text { mempunyai pengaruh yang } \\
\text { negatif terhadap volume } \\
\text { kredit yang disalurkan } \\
\text { NPL, LDR dan ROA }\end{array}$ \\
\hline
\end{tabular}




\begin{tabular}{|c|c|c|c|c|}
\hline & $\begin{array}{l}\text { Disalurkan Bank } \\
\text { Persero (Studi } \\
\text { Empirik Pada Bank } \\
\text { Persero di } \\
\text { Indonesia Periode } \\
\text { 2006-2011) }\end{array}$ & & $\begin{array}{l}\text { Dependen } \\
\text { Volume } \\
\text { Kredit } \\
\text { yang } \\
\text { disalurkan. }\end{array}$ & $\begin{array}{l}\text { Menunjukkan pengaruh } \\
\text { secara signifikan terhadap } \\
\text { volume kredit yang } \\
\text { disalurkan, Secara simultan } \\
\text { terdapat pengaruh yang } \\
\text { signifikan antara DPK, CAR, } \\
\text { NPL, ROA, LDR terhadap } \\
\text { Volume Kredit yang } \\
\text { disalurkan. }\end{array}$ \\
\hline 6 & $\begin{array}{l}\text { Elina Dyah } \\
\text { Permata } \\
\text { Manoppo, Tri Oldy } \\
\text { Rotinsulu dan } \\
\text { Albert Londa. } \\
\text { (2014) } \\
\text { Analisis Faktor } \\
\text { faktor } \\
\text { yang } \\
\text { Mempengaruhi } \\
\text { Penyaluran } \\
\text { Pembiayaan Pada } \\
\text { Bank Syariah di } \\
\text { Sulawesi Utara } \\
\text { Tahun 2010.1- } \\
\text { 2013.8 }\end{array}$ & $\begin{array}{l}\text { Uji Akar } \\
\text { Unit, Uji } \\
\text { Kointegra } \\
\text { si, dan } \\
\text { Uji } \\
\text { Asumsi } \\
\text { Klasik }\end{array}$ & $\begin{array}{l}\text { Variabel } \\
\text { independe } \\
\text { n : DPK, } \\
\text { NPL, } \\
\text { Tingkat } \\
\text { Inflasi. } \\
\text { Variabel } \\
\text { dependen : } \\
\text { Pembiayaa } \\
\text { n. }\end{array}$ & $\begin{array}{l}\text { Dana Pihak Ketiga (DPK) } \\
\text { Berpengaruh signifikan } \\
\text { terhadap pembiayaan, Non } \\
\text { Performing Loan (NPL) } \\
\text { berpengaruh tidak } \\
\text { signifikan terhadap } \\
\text { pembiayaan, Tingkat Inflasi } \\
\text { berpengaruh tidak } \\
\text { signifikan terhadap } \\
\text { pembiayaan,Secara } \\
\text { bersama-sama Dana Pihak } \\
\text { Ketiga (DPK), Non } \\
\text { Perfoming Loan (NPL) dan } \\
\text { Tingkat Inflasi berpengaruh } \\
\text { Terhadap pembiayaan. }\end{array}$ \\
\hline 7 & $\begin{array}{l}\text { Pratin dan Akhyar } \\
\text { Adnan. } \\
\text { (2005) } \\
\text { Analisis Hubungan } \\
\text { Simpanan, Modal } \\
\text { Sendiri, NPL, } \\
\text { Prosentase Bagi } \\
\text { Hasil dan Markup } \\
\text { Keuntungan } \\
\text { Terhadap } \\
\text { Pembiayaan Pada } \\
\text { Perbankan Syariah } \\
\text { Studi Kasus Pada } \\
\text { Bank Muamalat } \\
\text { Indonesia (BMI) } \\
\end{array}$ & $\begin{array}{l}\text { Least } \\
\text { Square } \\
\text { Method, } \\
\text { Uji } \\
\text { Asumsi } \\
\text { Klasik. }\end{array}$ & $\begin{array}{l}\text { Variabel } \\
\text { Independe } \\
\text { nt : DPK, } \\
\text { Modal } \\
\text { Sendiri } \\
\text { (Ekuitas), } \\
\text { NPL, } \\
\text { Margin. } \\
\text { Variabel } \\
\text { Dependen } \\
: \\
\text { Pembiayaa } \\
\text { n. }\end{array}$ & $\begin{array}{l}\text { DPK mempunyai } \\
\text { hubungan positif } \\
\text { secara signifikan terhadap } \\
\text { pembiayaan, Modal Sendiri } \\
\text { atau ekuitas mempunyai } \\
\text { hubungan positif } \\
\text { secara tidak signifikan } \\
\text { terhadap pembiayaan. NPL } \\
\text { mempunyai hubungan positif } \\
\text { tidak signifikan terhadap } \\
\text { pembiayaan, Margin } \\
\text { mempunyai hubungan negatif } \\
\text { tidak signifikan } \\
\text { terhadap pembiayaan. }\end{array}$ \\
\hline
\end{tabular}

\section{b. Keterkaitan Modal Sendiri, Dana Pihak Ketiga Terhadap Pembiayaan}

Beberapa variabel yang peneliti anggap paling dominan mempunyai keterkaitan dengan jumlah pembiayaan yang disalurkan oleh koperasi jasa keuangan syariah adalah modal sendiri dan dana pihak ketiga (DPK).

1) Keterkaitan Antara Modal Sendiri Dengan Pembiayaan

Menurut Siamat (993), Rose dan Kolari (1995), Syafi'i Antonio (2001), Suyatno (2001), Muhamad (2002), Sudarsono (2003), dan Karim (2004) dan Pratin dan Akhyar Adnan (2005:38), salah satu sumber dana yang bisa digunakan untuk pembiayaan (loan) adalah modal sendiri (ekuitas), sehingga semakin besar sumber dana (ekuitas) yang ada maka lembaga keuangan akan dapat menyalurkan pembiayaan dalam batas maksimum yang lebih besar pula.

2) Keterkaitan Dana Pihak Ketiga dengan Pembiayaan 
Dana-dana yang terhimpun dari masyarakat (Dana Pihak Ketiga) merupakan sumber dana terbesar yang paling diandalkan oleh lembaga keuangan (bisa mencapai $80 \%-90 \%$ ) dari seluruh dana yang dikelola. (Dendawijaya, 2005 dan Elina Dyah Permata Manoppo, Tri Oldy Rotinsulu dan Albert Londa (2014). Menurut Fitria Ayu Saryadi dan Andi Wijayanto (2011) peningkatan dana pihak ketiga (DPK) akan diikuti dengan peningkatan volume kredit yang disalurkan karena penyaluran kredit merupakan aktifitas yang menghasilkan pendapatan terbesar.

\section{Metode Penelitian}

\section{Ruang Lingkup Penelitian}

Dalam penelitian ini, penulis membatasi ruang lingkup penelitian sebagai berikut:

a. Sifat Penelitian

Penelitian yang penulis lakukan dalam penyusunan skripsi ini bersifat deskriktif kuantitatif, yaitu melakukan pembahasan atas permasalahan yang dihadapi oleh perusahaan terhadap kinerja perusahaan dari segi keuangan data-data analisa yang digunakan adalah data yang bersifat kuantitatif yatitu data-data yang bersifat angka.

\section{b. Jenis Penelitian}

Jenis penelitian ini adalah penelitian ekplanatif. Masalah penelitian ini menghubungkan satu fenomena dengan fenomena yang lain. Penelitian eksplanatif bertujuan untuk menghubungkan pola-pola yang berbeda, namun memiliki keterkaitan serta menghasilkan pola hubungan sebab akibat. Penelitian eksplanatif berupaya menjelaskan hubungan antara variabel satu dengan variabel yang lain, sehingga dapat dicirikan bahwa tipe perumusan masalah yang sifatnya eksplanatif, didalamnya perlu menunjukkan beberapa variabel yang akan dihubungkan.

Metode yang digunakan dalam penelitian ini adalah metode kuantitatif, yakni digunakan untuk meneliti pada populasi atau sampel tertentu, teknik pengumpulan sampel pada umumnya dilakukan secara random, pengumpulan data menggunakan instrumen penelitian, analisis data bersifat kuantitatif atau statistik dengan bertujuan untuk menguji hipotesis yang telah ditetapkan. Data yang digunakan berupa data laporan keuangan KOPPAS Tanah Abang Syariah seperti modal sendiri, dana pihak ketiga dan pembiayaan yang disalurkan dengan periode tahun 2011 hingga tahun 2016.

\section{c. Jadwal Penelitian}

Penelitian ini dilakukan penulis secara bertahap disesuaikan dengan tingkat kebutuhan selama 3 (tiga bulan).

\section{d. Objek dan Unit Analisis}

Yang menjadi objek dalam penelitian ini adalah KOPPAS Tanah Abang Syariah yang berada di Ruko Agropek Blok F3 No.15 Pasar Regional Tanah Abang, Jakarta Pusat. Unit analisis yang digunakan dalam penelitian ini diambil dari laporan keuangan KOPPAS Tanah Abang Syariah sebanyak 6 unit selama periode amatan 2011-2016.

\section{e. Variabel Penelitian}

Terdapat 3 (tiga) variabel yang akan diteliti dalam penelitian ini dimana terdapat 1 (satu) variabel dependen (variabel terikat) dan 2 (dua) variabel independen (bebas). Variabelnya adalah sebagai berikut:

1) Modal sendiri KOPPAS Tanah Abang Syariah sebagai variabel independen $\left(X_{1}\right)$. Modal sendiri merupakan semua dana yang dihimpun dari simpanansimpanan anggota KOPPAS Tanah Abang Syariah, dengan rumus sebagai berikut :

\section{Modal Sendiri $=\mathrm{SP}+\mathrm{SW}+\mathrm{SWK}+$ Cadangan $+\mathrm{SHU}$ Tahun Berjalan}

Keterangan :

SP $\quad=$ Simpanan Pokok 
SWK = Simpanan Wajib Khusus

$\mathrm{SHU}=$ Sisa Hasil Usaha

2). Dana pihak ketiga KOPPAS Tanah Abang Syariah sebagai variabel independen $\left(X_{2}\right)$. Dana pihak ketiga merupakan semua dana yang dihimpun dari nasabah penyimpan serta dana yang didapatkan dari lembaga keuangan lainnya, dengan rumus sebagai berikut :

$\mathrm{DPK}=\mathrm{TA}+\mathrm{SKB}+$ Hutang ke lembaga lainnya

Keterangan :

$\begin{array}{ll}\text { DPK } & =\text { Dana Pihak Ketiga } \\ \text { TA } & =\text { Tabungan Anggota } \\ \text { SKB } & =\text { Simpanan Koperasi Berjangka }\end{array}$

3). Pembiayaan yang disalurkan Koppas Tanah Abang Syariah sebagai variabel Dependen $(Y)$

\section{Metode Pengumpulan Data}

a. Sumber Data

Sumber data terdiri dari primer dan sekunder. Data primer adalah data yang diperoleh sendiri dari suatu organisasi atau perorangan langsung dari objeknya. Data sekunder adalah data yang diperoleh dalam bentuk yang sudah jadi, sudah dikumpulkan dan sudah diolah oleh pihak lain, biasanya sudah dalam bentuk publikasi. Data yang digunakan dalam penelitian ini merupakan data sekunder. Dalam penelitian ini data diperoleh dari laporan keuangan Koppas Tanah Abang Syariah periode tahun 2011 hingga tahun 2016.

b. Teknik Pengumpulan Data

1). Penelitian Perpustakaan (Library Research)

Bahan-bahan penelitian dilakukan dengan jalan menyelidiki buku- buku bacaan yang erat hubungannya dengan masalah yang dibahas.

Dengan kata lain penulis mengumpulkan, membaca, membandingkan serta menganalisa bahan yang dikemukakan oleh para ahli. Untuk itu penulis mengambil sikap dan pendapat dari hasil analisis dan perbandingan-perbandingan bahan-bahan tersebut.

2). Penelitian Lapangan (Field Research)

Yaitu cara mengumpulkan data dengan mengadakan penelitian langsung pada perusahaan untuk kemudian dipelajari, diolah dan dianalisa.

\section{Metode Analisis Data}

Metode analisis data adalah suatu metode yang digunakan untuk mengolah hasil penelitian guna memperoleh suatu kesimpulan. Dengan melihat kerangka pemikiran teoritis, maka teknik analisis data yang digunakan dalam penelitian ini adalah analisis kuantitatif. Untuk mendukung analisis tersebut digunakan software SPSS 20 untuk mempermudah perhitungan data penelitian ini.

a. Uji Asumsi Klasik

Uji asumsi klasik meliputi (1) uji normalitas; (2) Uji Heteroskedastisitas; (3) Uji Multikolinieritas; (4) Uji Autokorelasi;

\section{b. Analisis Regresi Linier Berganda}

Analisis linier berganda digunakan oleh peneliti bila peneliti bermaksud meramalkan bagaimana keadaan (naik turunnya) variabel dependen, bila dua atau lebih variabel independen sebagai factor predictor yang dinaik turunkan nilainya. Penelitian ini menggunakan model analisis regresi bergandadengan persamaan kuadrat terkecil atau ordinary least square (OLS) untuk menganalisis seberapa peranan modal sendiri, DPK terhadap pembiayaan yang disalurkan dengan model dasar sebagai berikut : $\quad \mathbf{Y}=$ $\boldsymbol{\alpha}+\boldsymbol{\beta}_{1} \boldsymbol{X}_{2}+\boldsymbol{\beta}_{2} \boldsymbol{X}_{2}$

Keterangan : 


$\begin{array}{ll}\mathrm{Y} & =\text { Pembiayaan } \\ \alpha & =\text { Konstanta } \\ \beta & =\text { Koefisien regresi } \\ X_{1} & =\text { Modal Sendiri } \\ X_{2} & =\text { Dana pihak ketiga }\end{array}$

Untuk bisa membuat ramalan melalui regresi, maka data setiap variabel harus tersedia. Selanjutnya berdasarkan data tersebut peneliti harus menemukan persamaan melalui perhitungan.

\section{1). Uji Signifikansi (Uji Statistik t)}

Uji statistik t pada dasarnya menunjukan seberapa jauh variabel penjelas secara individual dalam menerangkan variasi variabel terikat. Nilai t hitung digunakan untuk menguji apakah variabel tersebut berpengaruh secara signifikan terhadap variabel tergantung atau tidak. Suatu variabel akan memiliki pengaruh yang berarti jika nilai $t$ hitung variabel tersebut lebih besar dibanding t tabel.

Dalam tabel distribusi t terdapat istilah satu ujung dan dua ujung. Penggunaan tabel satu ujung dan dua ujung tergantung pada hipotesis yang diajukan. Jika hipotesis yang diajukan sudah menunjukkan arah, misalnya terdapat pengaruh positif, maka menggunakan satu ujung sebelah kanan. Akan tetapi jika belum menunjukkan arah, misalnya terdapat pengaruh (tidak menunjukkan pengaruh positif atau negatif) maka menggunakan dua ujung. Jika menggunakan satu ujung maka df : $\alpha, n-k$, tetapi jika menggunakan dua ujung maka derajat bebasnya adalah df : $\alpha_{2}$, n-k. Untuk menghitung besarnya t maka digunakan rumus berikut : $t=\frac{b j}{s b j}$

Keterangan: $\quad t=$ Nilai thitung; bj = Koefisien regresi

$$
\mathrm{Sbj}=\text { Kesalahan baku koefisien regresi }
$$

\section{2) Uji Signifikansi Simultan (Uji Statistik F)}

Uji statistik $F$ pada dasarnya menunjukan apakah semua variabel bebas yang dimasukkan dalam model mempunyai pengaruh secara bersama-sama terhadap variabel terikat. Nilai $\mathrm{F}$ hitung digunakan untuk menguji ketepatan model atau goodness of fit, apakah model persamaan yang terbentuk masuk dalam kriteria cocok (fit) atau tidak. Uji $F$ ini juga sering disebut sebagai uji simultan, yaitu untuk menguji apakah variabel bebas yang digunakan dalam model mampu menjelaskan perubahan nilai variabel tergantung atau tidak. Untuk menyimpulkan apakah model masuk dalam kategori cocok (fit) atau tidak, kita harus membandingkan nilai $F$ tabel dengan df : $(k-1),(n-k)$. Untuk menghitung besarnya nilai $\mathrm{F}$ hitung digunakan formula sebagai berikut :

$$
\begin{aligned}
& \boldsymbol{F}=\frac{\boldsymbol{R} \mathbf{2} /(\boldsymbol{K}-\mathbf{1})}{\mathbf{1}-\boldsymbol{R} \mathbf{2} /(\boldsymbol{n}-\boldsymbol{k})} \\
& \text { Keterangan : } \\
& \mathrm{F} \quad=\text { Nilai F hitung } \\
& R^{2} \quad=\text { Koefisien determinasi } \\
& K \quad=\text { Jumlah variabel } \\
& N \quad=\text { Jumlah pengamatan (ukuran sampel). }
\end{aligned}
$$

\section{3) Koefisien Korelasi}

Koefisien korelasi adalah nilai yang menunjukkan kuat atau tidaknya hubungan linier antar dua variabel. Koefisien korelasi biasa dilambangkan dengan huruf $r$ dapat bervariasi dari 1 sampai +1 . Nilai $r$ yang mendekati -1 atau +1 menunjukkan hubungan yang kuat antara dua variabel tersebut dan nilai $r$ yang mendekati 0 mengindikasikan lemahnya hubungan antara dua variabel tersebut. Jika bernilai + (positif) maka kedua variabel tersebut memiliki hubungan yang searah. Dalam arti lain peningkatan $\mathrm{X}$ akan bersamaan dengan 
peningkatan $Y$ dan begitu juga sebaliknya. Jika bernilai - (negatif) artinya korelasi antara kedua variabel tersebut bersifat berlawanan. Peningkatan nilai $X$ akan bersamaan dengan penurunan $\mathrm{Y}$.

4) Koefisien Determinasi $\left(\mathbf{R}^{2}\right)$

Koefisien determinasi $\left(R^{2}\right)$ pada intinya mengukur seberapa jauh kemampuan model dalam menerangkan variabel-variabel terikat. Formula untuk menghitung besarnya koefisien determinasi sebagai berikut :

$R^{2}=1-\frac{\sum(Y-\widehat{Y})^{2}}{\sum(Y-\bar{Y})^{2}}$

Keterangan :

$R^{2} \quad=$ Koefisien determinasi

$(Y-\widehat{Y})^{2} \quad=$ Kuadrat selisih nilai $Y$ riil dengan nilai $Y$ prediksi

$(Y-\bar{Y})^{2} \quad=$ Kuadrat selisih nilai $Y$ riil dengan nilai $Y$ rata-rata

\section{Hasil Penelitian Dan Pembahasan}

\section{a. Data Ringkas KOPPAS Tanah Abang Syari'ah}

Berikut data ringkas KOPPAS Tanah Abang Syari,ah sebagai obyek penelitian yang relevan dan dirangkum serta diolah untuk masing-masing variabel $X_{1}$ (Modal Sendiri), $X_{2}$ (Dana Pihak Ketiga) dan Y (Pembiayaan) periode tahun 2011-2016 diuraikan pada tabel berikut :

Tabel 4.1

Data Modal Sendiri, DPK dan Pembiayaan KOPPAS Tanah Abang Syariah

(Dalam Jutaan Rupiah)

\begin{tabular}{|l|c|c|c|c|c|c|}
\hline \multicolumn{1}{|c|}{ Keterangan / Tahun } & 2011 & 2012 & 2013 & 2014 & 2015 & 2016 \\
\hline Modal Sendiri & 4.899 & 5.304 & 5.927 & 6.985 & 6.677 & 3.597 \\
\hline Simp.Berjangka & 3.881 & 5.401 & 6.886 & 8.006 & 5.709 & 6.696 \\
\hline Tabungan & 2.268 & 3.102 & 4.009 & 4.230 & 4.131 & 4.740 \\
\hline Hutang ke Lembaga Lainnya & 4.459 & 6.714 & 8.439 & 2.007 & 2.253 & 11.976 \\
\hline Total Dana Pihak Ke III & 10.608 & 15.217 & 19.334 & 14.243 & 12.093 & 22.269 \\
\hline Pembiayaan & 13.007 & 15.380 & 17.994 & 17.627 & 12.933 & 10.341 \\
\hline
\end{tabular}

Sumber : Neraca KOPPAS Tanah Abang Syariah periode tahun 2011-2016

Pembahasan penelitian pada masing-masing sampel variabel penelitian, pengujian, pemodelan, hasil dan interpretasi pengaruh variabel bebas (independent) terhadap varibel terikat (dependent) dan pengujian hipotesis dijelaskan sebagai berikut :

\section{Analisis Perkembangan Modal Sendiri, Dana Pihak Ketiga dan Pembiayaan}

Perkembangan modal sendiri, dana pihak ketiga dan pembiayaan dapat dilihat pada tabel berikut ini :

Tabel 4.2

Perkembangan Modal Sendiri, Dana Pihak Ketiga dan Pembiayaan

Koppas Tanah Abang Syariah

(dalam jutaan rupiah) 


\begin{tabular}{|c|c|c|c|c|c|c|}
\hline Tahun & $\begin{array}{c}\text { Modal } \\
\text { Sendiri }\end{array}$ & $\Delta$ & DPK & $\Delta$ & $\begin{array}{c}\text { Pembiaya } \\
\text { an }\end{array}$ & $\Delta$ \\
\hline 2011 & 4.899 & & 10.608 & & 13.007 & \\
\hline 2012 & 5.304 & 405 & 15.217 & 4.609 & 15.380 & 2.373 \\
\hline 2013 & 5.927 & 623 & 19.334 & 4.063 & 17.994 & 2.614 \\
\hline 2014 & 6.985 & 1058 & 14.243 & -5.091 & 17.627 & -367 \\
\hline 2015 & 6.677 & -308 & 12.093 & -2.150 & 12.933 & -4.694 \\
\hline 2016 & 3.597 & 3.080 & 22.269 & 10.093 & 10.341 & -2.592 \\
\hline $\begin{array}{c}\text { Peningkatan } \\
\text { Rata-rata } \\
\text { Pertahun }\end{array}$ & & -217 & & 1.485 & & -446 \\
\hline
\end{tabular}

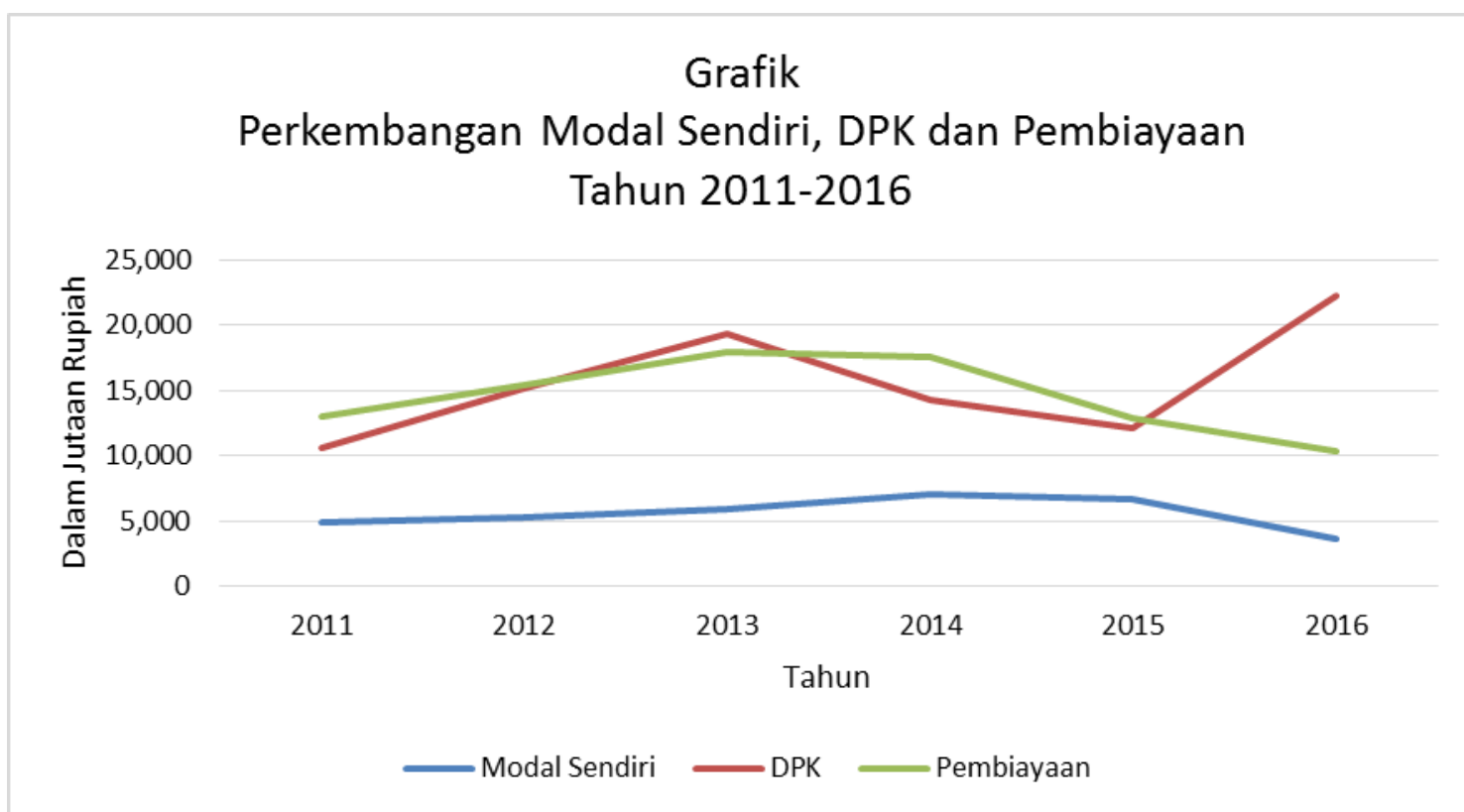

Dari tabel 4.2 menunjukkan bahwa modal sendiri dari tahun 2011 ke 2012 bertambah sebesar 405 juta, tahun 2013 bertambah sebesar 623 juta, tahun 2014 bertambah sebesar 1.056 juta, tahun 2015 modal sendiri mengalami penurunan sebesar 308 juta, kemudian tahun 2016 menurun sebesar 3.597 juta. Rata-rata pertahun modal sendiri mengalami kenaikan sebesar 810 juta.

Perkembangan dana pihak ketiga dari tahun 2011 ke tahun 2012 mengalami kenaikan sebesar 4.609 juta, tahun 2013 naik sebesar 4.063 juta, tahun 2014 mengalami penurunan sebesar 5.091 juta, tahun 2015 tingkat dana pihak ketiga turun kembali sebesar 2.150 dan tahun 2016 mengalami penurunan sebesar 10.093 juta dengan ratarata penurunan dana pihak ketiga sebesar 1.485 juta pertahun.

Perkembangan pembiayaan dari tahun 2011 ke tahun 2012 mengalami kenaikan sebesar 2.373 juta, tahun 2013 naik sebesar 2.614, tahun 2014 mengalami penurunan sebesar 367, tahun 2015 mengalami penurunan drastis sebesar 4.694, kemudian tahun 2016 menurun sebesar 2.592 juta. Pembiayaan mengalami penurunan dengan rata-rata pertahun adalah sebesar 446 juta.

\section{Uji Asumsi Klasik}

\section{a. Uji Normalitas}

Pengujian normalitas pada variabel $X_{1}$ Modal Sendiri, $X_{2}$ Dana Pihak Ketiga terhadap $Y$ Pembiayaan diperoleh hasil seperti terlihat pada histogram dibawah ini. Terlihat bahwa 
data sudah mendekati bentuk standar distribusi normal, yaitu sebaran data berbentuk lonceng terbalik (Jonathan Sarwono, 2012).

Kemudian dilakukan pengujian Linieritas untuk mengetahui apakah ada hubungan linier antara variabel independent dan dependent. Dari hasil pengolahan data maka diperoleh grafik Normal P-P Plot of Regression Standarized Residual untuk dependent variable Pembiayaan.

\section{b. Uji Heteroskedastisitas}

Grafik dibawah ini menunjukkan adanya hubungan antara variabel independent dan dependent, jika kita lihat sebaran datanya berpencar disekitar angka nol dan tidak membentuk suatu pola atau kecenderungan tertentu, maka dengan demikian data ini telah layak memenuhi syarat heteroskedastisitas dan model regresi layak digunakan untuk memprediksi (Jonathan Sarwono, 2012).

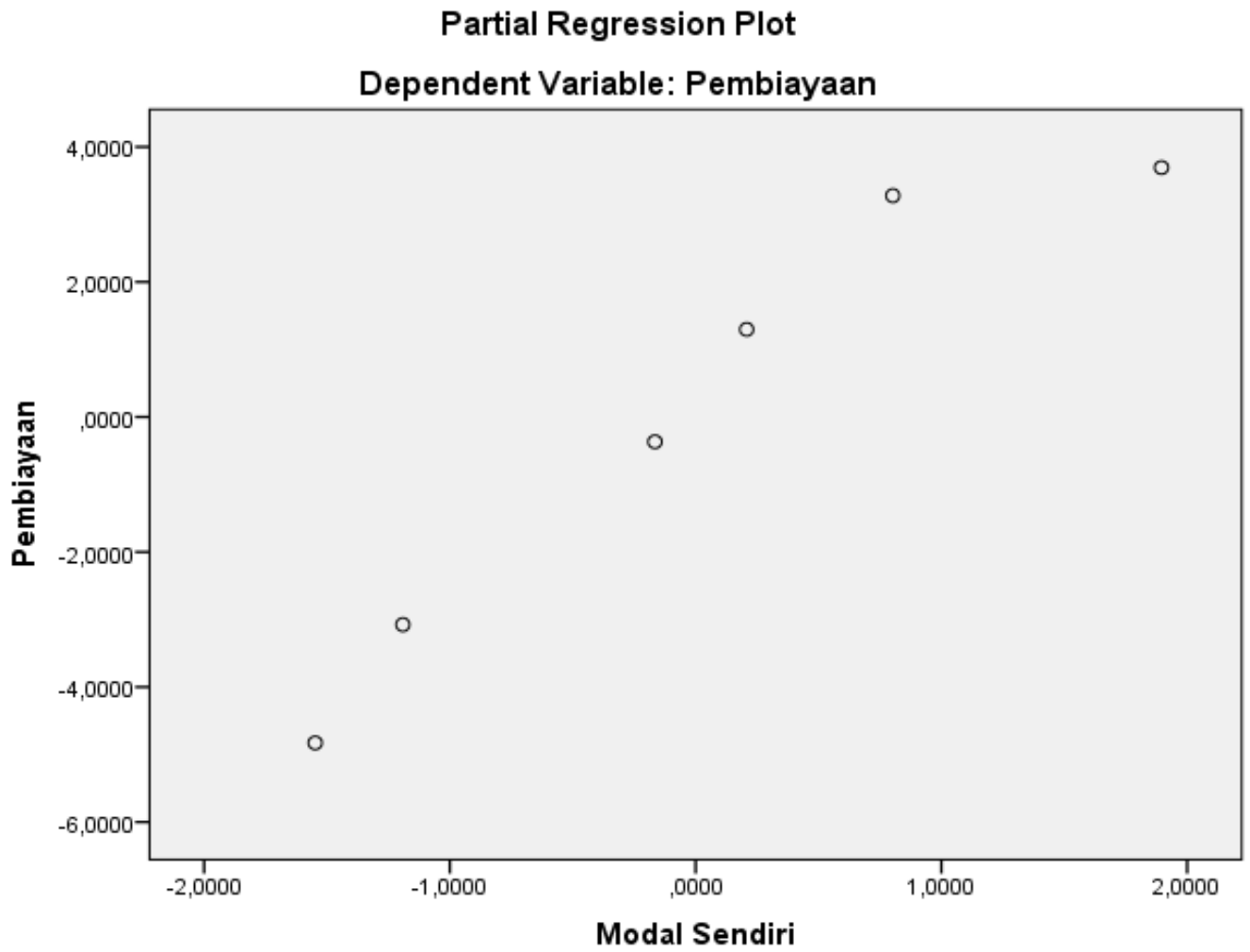

Sumber : Data sekunder yang diolah menggunakan SPSS 20

\section{c. Uji Autokorelasi}

Model Summary ${ }^{b}$

\begin{tabular}{|l|r|r|r|r|r|}
\hline Model & $\mathrm{R}$ & $\mathrm{R}$ Square & $\begin{array}{c}\text { Adjusted R } \\
\text { Square }\end{array}$ & $\begin{array}{c}\text { Std. Error of the } \\
\text { Estimate }\end{array}$ & $\begin{array}{c}\text { Durbin } \\
- \\
\text { Watso } \\
\mathrm{n}\end{array}$ \\
\hline 1 &, $966^{\mathrm{a}}$ &, 933 &, 889 & 1,1781934 & 1,615 \\
\hline
\end{tabular}

a. Predictors: (Constant), Dana Pihak Ketiga, Modal Sendiri

b. Dependent Variable: Pembiayaan

Sumber : Data Sekunder yang diolah menggunakan SPSS 20

Hasil perhitungan nilai Durbin Watson pada model adalah sebesar 1,615 dengan demikian bahwa dalam penelitian ini tidak terjadi Autokorelasi (Anderson et al, 2011). 


\section{d. Uji Multikolinieritas}

Coefficients $^{\mathrm{a}}$

\begin{tabular}{|l|r|r|}
\hline Model & \multicolumn{2}{|c|}{ Collinearity Statistics } \\
\cline { 2 - 3 } & Tolerance & \multicolumn{1}{|c|}{ VIF } \\
\hline (Constant) &, 999 & 1,001 \\
Modal Sendiri &, 999 & 1,001 \\
Dana Pihak Ketiga & \\
\hline
\end{tabular}

a. Dependent Variable: Pembiayaan

Sumber : Data Sekunder yang diolah menggunakan SPSS 20.

Pengujian yang

dilakukan pada model regresi linier berganda, menunjukkan nilai VIF variabel X1 Modal Sendiri dan variabel X2 Dana Pihak Ketiga sebesar 1,001. Semua nilai VIF pada model regresi linier berganda menunjukkan hasil VIF $<5$ atau VIF $<10$ hal ini dapat dikatakan bahwa penelitian ini tidak terjadi multikolinieritas (Eddy Supriyadi, 2012)

\section{Analisis Koefisien Korelasi dan Uji Koefisien Determinasi}

\section{a. Uji Koefisien Korelasi}

\section{Correlations}

\begin{tabular}{|ll|r|r|r|}
\hline & & Pembiayaan & Modal Sendiri & $\begin{array}{c}\text { Dana Pihak } \\
\text { Ketiga }\end{array}$ \\
\hline Pearson & Pembiayaan & 1,000 &, 944 &, 232 \\
Correlation & Modal Sendiri &, 944 & 1,000 &, 029 \\
& Dana Pihak Ketiga &, 232 &, 029 & 1,000 \\
& Pembiayaan &, 002 &, 002 &, 329 \\
Sig. (1-tailed) & Modal Sendiri &, 329 &, 478 &, 478 \\
& Dana Pihak Ketiga & 6 & 6 & 6 \\
& Pembiayaan & 6 & 6 & 6 \\
& Modal Sendiri & 6 & 6 & 6 \\
\hline
\end{tabular}

Dari hasil pengolahan data menggunakan SPSS 20 dapat dilihat bahwa uji koefisien korelasi ( $r$ ) menunjukkan angka sebesar 0,944 yang berarti bahwa variabel X1 modal sendiri berpengaruh sangat kuat terhadap $Y$ pembiayaan sedangkan $X 2$ dana pihak ketiga terhadap $\mathrm{Y}$ pembiayaan berpengaruh lemah atau kurang kuat karena hanya menunjukkan nilai sebesar 0,232.

\section{b. Uji Koefisien Determinasi}

Model Summary ${ }^{b}$

\begin{tabular}{|l|r|r|r|r|r|}
\hline Model & \multicolumn{1}{|c|}{$\mathrm{R}$} & $\mathrm{R}$ Square & $\begin{array}{l}\text { Adjusted R } \\
\text { Square }\end{array}$ & $\begin{array}{r}\text { Std. Error of } \\
\text { the Estimate }\end{array}$ & $\begin{array}{r}\text { Durbin- } \\
\text { Watson }\end{array}$ \\
\hline 1 &, $966^{\mathrm{a}}$ &, 933 &, 889 & 1,1781934 & 1,615 \\
\hline
\end{tabular}

a. Predictors: (Constant), Dana Pihak Ketiga, Modal Sendiri

b. Dependent Variable: Pembiayaan

Sumber : Data sekunder diolah menggunakan SPSS 20 
Uji koefisien determinasi dapat dilihat dari $R$ square. Dari hasil pengolahan data menggunakan SPSS 20 dapat dilihat bahwa nilai $R$ square menunjukkan angka sebesar 0,933 yang berarti bahwa variabel X1 Modal Sendiri dan X2 Dana Pihak Ketiga berpengaruh sangat kuat terhadap pembiayaan sebesar $93,3 \%$ sedangkan sisanya sebesar 6,7\% dipengaruhi oleh faktor lain yang tidak diteliti dalam penelitian ini (Jonathan Sarwono, 2012)

\section{Analisis Regresi Linier Berganda}

a. Uji Signifikansi (Uji Parsial t)

Coefficients $^{\mathrm{a}}$

\begin{tabular}{|c|c|c|c|c|c|}
\hline \multirow[t]{2}{*}{ Model } & \multicolumn{2}{|c|}{$\begin{array}{l}\text { Unstandardized } \\
\text { Coefficients }\end{array}$} & \multirow{2}{*}{$\begin{array}{c}\text { Standardized } \\
\text { Coefficients } \\
\text { Beta }\end{array}$} & \multirow[t]{2}{*}{$\mathrm{t}$} & \multirow[t]{2}{*}{ Sig. } \\
\hline & $B$ & Std. Error & & & \\
\hline \multirow{3}{*}{$\begin{array}{l}\text { (Constant) } \\
\text { Modal Sendiri } \\
\text { Dana Pihak } \\
\text { Ketiga }\end{array}$} & $-1,224$ & 2,584 & &,- 474 &, 668 \\
\hline & 2,598 & , 413 & ,938 & 6,283 &, 008 \\
\hline & , 136 & ,099 & 205 & 1,373 &, 263 \\
\hline
\end{tabular}

Sumber : Data Sekunder yang diolah menggunakan SPSS 20

Hasil uji t variabel $X 1$ Modal Sendiri terhadap variabel $Y$ Pembiayaan menunjukkan nilai $t$ sebesar 6,283 dengan nilai signifikansi sebesar 0,8. Dengan demikian dapat disimpulkan bahwa secara parsial Modal Sendiri berpengaruh positif dan sangat signifikan terhadap pembiayaan.

Selanjutnya hasil uji t variabel X2 Dana Pihak Ketiga terhadap variabel Y Pembiayaan menunjukkan nilai t sebesar 1,373 dengan nilai signifikansi sebesar 26,3. Dengan demikian dapat disimpulkan bahwa secara parsial Dana Pihak Ketiga berpengaruh akan tetapi tidak signifikan terhadap pembiayaan.

\section{b. Uji Signifikansi Simultan (Uji Statistik F)}

Uji simultan (uji F) digunakan untuk menguji variabel bebas X1 (Modal Sendiri) dan X2 (Dana Pihak Ketiga) secara bersama-sama berpengaruh terhadap variabel $Y$ (Pembiayaan).

\begin{tabular}{|l|r|r|r|r|l|}
\hline \multicolumn{1}{|c|}{ MNOVA $^{\mathrm{a}}$} \\
& \multicolumn{1}{|c|}{$\begin{array}{c}\text { Sum of } \\
\text { Squares }\end{array}$} & \multicolumn{1}{c|}{ df } & $\begin{array}{c}\text { Mean } \\
\text { Square }\end{array}$ & $\mathrm{F}$ & Sig. \\
\hline Regression & 58,146 & 2 & 29,073 & 20,944 &, $017^{\mathrm{b}}$ \\
1 Residual & 4,164 & 3 & 1,388 & & \\
Total & 62,310 & 5 & & & \\
\hline
\end{tabular}

a. Dependent Variable: Pembiayaan

b. Predictors: (Constant), Dana Pihak Ketiga, Modal Sendiri

Sumber : Data sekunder diolah menggunakan SPSS 20

Hasil uji F antara variabel X1 Modal Sendiri dan X2 Dana Pihak Ketiga terhadap variabel Y Pembiayaan menunjukkan nilai $F$ sebesar 20,944 dengan nilai signifikansi sebesar 1,7. Dengan demikian dapat disimpulkan bahwa secara simultan Modal Sendiri dan Dana Pihak ketiga berpengaruh positif dan signifikan terhadap Pembiayaan yang disalurkan KOPPAS Tanah Abang Syariah periode tahun 2011-2016. Dengan demikian diperoleh Model Regresi Penelitian adalah sebagai berikut:

$Y=-1,224+2,598 X_{1}+0,136 X_{2}$ 


\section{E. Hasil Pembahasan \\ 1. Uji Asumsi Klasik \\ a. Uji Normalitas}

Pengujian normalitas pada variabel X1 Modal Sendiri, X2 Dana Pihak Ketiga terhadap Y Pembiayaan diperoleh hasil bahwa data sudah mendekati bentuk standar distribusi normal, yaitu sebaran data berbentuk lonceng terbalik. Kemudian dilakukan pengujian Linieritas dari grafik normal menunjukkan bahwa terdapat hubungan linier antara variabel independent dan dependent terlihat bahwa sebaran data mengikuti garis lurus dari kiri bawah ke kanan atas.

\section{b. Uji Heteroskedastisitas}

Sebaran datanya berpencar disekitar angka nol dan tidak membentuk suatu pola atau kecenderungan tertentu, maka dengan demikian data ini telah layak memenuhi syarat heteroskedastisitas dan model regresi layak digunakan untuk memprediksi.

\section{c. Uji Autokorelasi}

Hasil perhitungan nilai Durbin Watson pada model adalah sebesar 1,615 dengan demikian bahwa dalam penelitian ini tidak terjadi Autokorelasi.

\section{d. Uji Multikoliniritas}

Nilai VIF variabel X1 Modal Sendiri dan variabel X2 Dana Pihak Ketiga sebesar 1,001. Semua nilai VIF pada model regresi linier berganda menunjukkan hasil VIF $<5$ atau VIF $<$ 10 hal ini dapat dikatakan bahwa penelitian ini tidak terjadi multikolinieritas.

\section{Uji Koefisien Korelasi dan Koefiisien Determinasi \\ a. Uji Koefisien Korelasi}

Dari hasil pengolahan data menggunakan SPSS 20 dapat dilihat bahwa uji koefisien korelasi $\left(r\right.$ ) menunjukkan angka sebesar 0,944 yang berarti bahwa variabel $X_{1}$ modal sendiri berpengaruh sangat kuat terhadap $\mathrm{Y}$ pembiayaan sedangkan $\mathrm{X}_{2}$ dana pihak ketiga terhadap $\mathrm{Y}$ pembiayaan berpengaruh lemah atau kurang kuat karena hanya menunjukkan nilai sebesar 0,232 .

\section{b. Koefisien Determinasi}

Uji koefisien determinasi dapat dilihat dari $R$ square. Dari hasil pengolahan data menggunakan SPSS 20 dapat dilihat bahwa nilai $R$ square menunjukkan angka sebesar 0,933 yang berarti bahwa variabel X1 Modal Sendiri dan X2 Dana Pihak Ketiga berpengaruh sangat kuat terhadap pembiayaan sebesar $93,3 \%$ sedangkan sisanya sebesar $6,7 \%$ dipengaruhi oleh faktor lain yang tidak diteliti dalam penelitian ini.

\section{Analisis Regresi Linier Berganda}

\section{a. Uji Parsial (Uji t)}

Hasil uji $t$ variabel $\mathbf{X}_{1}$ (Modal Sendiri) terhadap variabel $Y$ (Pembiayaan) menunjukkan nilai t sebesar 6,283 dengan nilai signifikansi sebesar 0,008 atau 0,8\%. Dengan demikian dapat disimpulkan bahwa secara parsial modal sendiri berpengaruh positif dan sangat signifikan terhadap pembiayaan.

Selanjutnya hasil uji t variabel $\mathrm{X}_{2}$ (Dana Pihak Ketiga) terhadap variabel $\mathrm{Y}$ (Pembiayaan) menunjukkan nilai t sebesar 1,373 dengan nilai signifikansi sebesar 0,263 atau $26,3 \%$. Dengan demikian dapat disimpulkan bahwa secara parsial dana pihak ketiga berpengaruh tidak signifikan terhadap pembiayaan.

b. Uji Simultan (Uji F)

Hasil uji $F$ antara variabel $X_{1}$ (Modal Sendiri) dan $X_{2}$ (Dana Pihak Ketiga) terhadap variabel $Y$ (Pembiayaan) menunjukkan nilai $F$ sebesar 20,944 dengan nilai signifikansi sebesar 0,017 atau $1,7 \%$. Dengan demikian dapat disimpulakan bahwa secara simultan modal sendiri dan dana pihak ketiga berpengaruh positif dan signifikan terhadap pembiayaan yang disalurkan KOPPAS Tanah Abang Syariah periode tahun 2011-2016. 


\section{F. Kesimpulan Dan Saran}

\section{Kesimpulan}

Berdasarkan hasil penelitian maka didapat beberapa kesimpulan sebagai berikut :

a. Perkembangan modal sendiri KOPPAS Tanah Abang Syariah rata-rata pertahun mengalami penurunan sebesar 217 juta, dana pihak ketiga mengalami kenaikan dengan rata-rata pertahun sebesar 1.920 juta dan penyaluran pembiayaan mengalami penurunan dengan rata-rata pertahun sebesar 446 juta.

b. Terdapat pengaruh positif dan sangat signifikan antara modal sendiri terhadap pembiayaan yang disalurkan KOPPAS Tanah Abang Syariah. Hal ini dapat dibuktikan dengan hasil uji t yang menunjukkan nilai sebesar 6,283 dan hasil signifikansi sebesar 0,008 atau $0,8 \%$.

c. Terdapat pengaruh tidak signifikan antara dana pihak ketiga terhadap pembiayaan yang disalurkan KOPPAS Tanah Abang Syariah. Hal ini dapat dibuktikan dengan hasil uji t yang menunjukkan nilai sebesar 1,373 dan hasil tidak signifikansi sebesar 0,263 atau $26,3 \%$.

d. Modal sendiri dan dana pihak ketiga berpengaruh positif dan signifikan terhadap pembiayaan yang disalurkan KOPPAS Tanah Abang Syariah. Hal ini dapat dibuktikan dengan hasil uji $F$ yang menunjukkan nilai $F$ sebesar 20,944 dengan nilai signifikansi sebesar 0,017 atau $1,7 \%$.

e. Terdapat pengaruh yang sangat kuat antara variabel $X_{1}$ modal sendiri dan $X_{2}$ dana pihak ketiga terhadap pembiayaan sebesar $93,3 \%$ yang dapat dilihat dari nilai $R$ square yang menunjukkan nilai 0,933 . Sedangkan sisanya $6,7 \%$ dipengaruhi oleh faktor lain yang tidak diteliti dalam penelitian ini.

f. Modal sendiri dan dana pihak ketiga mempunyai peranan yang sangat penting terhadap penyaluran pembiayaan di KOPPAS Tanah Abang Syariah.

\section{Keterbatasan Penelitian}

Cakupan variabel pembiayaan terlalu luas, meliputi semua pembiayaan yang ada di KOPPAS Tanah Abang Syariah, seperti mudharabah, murabahah, ijarah dan hawalah sehingga penelitian hasilnya kurang fokus. Hal ini dilakukan karena salah satu data masing-masing pembiayaan tidak tersedia, data laporan yang ada merupakan pembiayaan gabungan, yaitu dicatat atau dilaporkan pembiayaan yang diberikan.

\section{Saran}

Dari penelitian yang telah dilakukan, maka dapat disarankan sebagai berikut:

a. Bagi pihak KOPPAS Tanah Abang Syariah sebaiknya tetap menjaga himpunan dana baik dari dana pihak ketiga maupun modal sendiri dengan cara terus melakukan inovasi terhadap produk-produk serta strategi dalam menarik perhatian calon nasabah maupun meningkatkan loyalitas nasabah.

b. Untuk penelitian selanjutnya diharapkan menggunakan objek yang berbeda dan menambah variabel-variabel lain agar memperoleh hasil yang bervariatif yang dapat menggambarkan hal-hal apa saja dapat berpengaruh terhadap pembiayaan . 


\section{G. Daftar Pustaka}

Ahmad Ronodi \& Indiyana N "Bank dan Lembaga Keuangan Lainnya" Jakarta: Center for Social Economics Studies, 2007

Anderson, David R. Dennis J. Sweeney and Thomas A. Williams, "Statistics for Business and Economics, Eleventh Edition”, South-Western: Cengage Learning 2011

Arifin Z “Dasar-Dasar Manajemen Bank Syariah”, Jakarta:Alfabet, 2003-2006

Bambang Riyanto, “Dasar-Dasar Pembelanjaan Perusahaan”. Yogyakarta: BPFE, 2002.

Barrett, Richard, "Training, Developing and Motivating People", Vocational Businnes, 2013

Deni Darmawan “Metode Penelitian Kuantitatif” Bandung: PT Remaja Rosdakarya, 2013

Djazh, Dahlan, “Pengetahuan Koperasi”, Jakarta:PN Balai Pustaka, 1980

Eddy Supriyadi, “SPSS AMOS Statistical Data Analysis” Jakarta: In Media, 2014

Elina Dyah Permata Manoppo, Tri Oldy Rotinsulu dan Albert Londa, "Faktor-Faktor yang Mempengaruhi Penyaluran Pembiayaan Pada Bank Syariah di Sulawesi Utara Tahun 2010-2013", Jurnal Berkala IImiah Efisiensi,Vol. 14 No. 1, h.63-72, 2014.

Graffin, R “Business 8th Edition", NJ: Prentice Han, 2006

Handoko, T. Hani, "Manajemen”. Edisi kedua, cetakan kedua puluh satu, Yogyakarta: BPFE, 2011.

Hans, “Prinsip-Prinsip Koperasi dan UU Koperasi”, Direktorat Jenderal Koperasi, 1980

Haryadi Sarjono dan Winda Yulianita, "SPSS vs LISREAL Sebuah Pengantar, Aplikasi Untuk Riset" Jakarta: Salemba Empat 2011

Hendar \& Kusnadi, “Ekonomi Koperasi”, Lembaga Penerbit FE UI, 2005

James C, Van Horne dan John M. Wachowicz, "Prinsip-prinsip Manajemen Keuangan. Edisi kedua belas”. Jakarta: Salemba Empat, 2005.

Jonathan, Sarwono, "Mengenal SPSS Statistics 20 Aplikasi untuk Riset Ekperimental" Jakarta : Penerbit PT Elex Media Komputindo - Kompas Gramedia, 2012

Juhandi, Nendi, "Manajemen Keuangan", Cetakan pertama. Cibubur: Pelangi Nusantara, 2007.

Kasmir, “Dasar-Dasar Perbankan”, edisi pertama, Jakarta: Raja Grafindo Persada, 2005.

Khodijah, Hidayyatul Maula, "Pengaruh Simpanan (Dana Pihak Ketiga), Modal Sendiri, Margin Keuntungan, dan NPF (Non Performing Financial) Terhadap Pembiayaan Murabahab Pada Bank Syariah Mandiri”, Yogyakarta:Universitas Islam Negeri Sunan Kalijaga, 2008. 
Manullang, M, "Dasar-Dasar Manajemen". Yogyakarta: Gajah Mada University Press, 2009.

Mardiyatmo,"Kewirausahaan", Jakarta: Yudistira, 2008.

Martono dan Agus Harjitno, “Manajemen Keuangan”Yogyakarta: Ekonesia, 2003

Moh. Sidik Priadana dan Saludin Muis, "Metodologi Penelitian Ekonomi dan Bisnis"Yogyakarta: Graha IImu, 2009

Muhammad "Metodologi Penelitian Ekonomi Islam Pendekatan Kuantitatif, Jakarta: PT Grafindo Persada, 2008

Nardi Sunardi (2018) "Analisis Risk Based Bank Rating (RBBR) Untuk Mengukur Tingkat Kesehatan Bank Syariah Di Indonesia" JIMF (Jurnal IImiah Manajemen Forkamma), Program Pascasarjana Universitas Pamulang, p-ISSN : 2598-9545, e-ISSN : 2599171X, Vol 1, Vol.2, No.1, Februari 2018, Hal : $50-66$

Ni'mah, Kholisatun, “Analisis Pengaruh Dana Pihak Ketiga, Modal Sendiri, Return On Asset dan Financing to Deposit Ratio Terhadap Pembiayaan yang disalurkan Pada Bank BRI Syariah Pada Tahun 2010-2014", Semarang: Universitas Islam Negeri Walisongo Semarang, 2015.

Pratin dan Akhyar Adnan, "Analisis Hubungan Simpanan, Modal Sendiri, NPL, Prosentase Bagi Hasil dan Markup Keuntungan Terhadap Pembiayaan Pada Perbankan Syariah Studi Kasus Pada Bank Muamalat Indonesia (BMI)", h. 35-52, 2005.

Robbins, Stephen P \& Mary Coulter, "Manajemen jilid I/ Stephen P Robbins dn Mary Coulter diterjemahkan oleh Bob Sabran, Wibi Hardani. -Ed.10, Cet. 13". Jakarta: Airlangga, 2010.

Sofyan Siregar, "Statistika Deskriptif Untuk Penelitian" PT. Raja Grafindo Persada:Jakarta, 2010

Sugiyono, "Metode Penelitian Pendidikan Pendekatan Kuantitatif, Kuantitatif dan R \& D", Bandung: Alfabeta, 2019

Suliyanto, "Ekonometrika Terapan Teori, Aplikasi dan SPSS" Yogyakarta: CV Andi, 2011

Syariah di Indonesia Periode Tahun 2007-2013", Economics Development Analysis Journal, Vol. 2 No. 4, h.367-383, 2013.

Umar, Yasril, "Pengaruh Tingkat Bagi Hasil, Kualitas Pelayanan dan Citra Koperasi", Jakarta: Universitas Mercu Buana, 2014.

Wuri Arianti Novi Pratami, "Analisis Pengaruh Dana Pihak Ketiga (DPK), Capital Adequacy Ratio (CAR), Non Performing Financing (NPF) dan Return On Asset (ROA) Terhadap Pembiayaan Pada Perbankan Syariah (Studi Kasus Pada Bank Muamalat Indonesia Periode 2001- 2011)", Semarang : Universitas Diponegoro, 2011.

http://www.google.co.id 